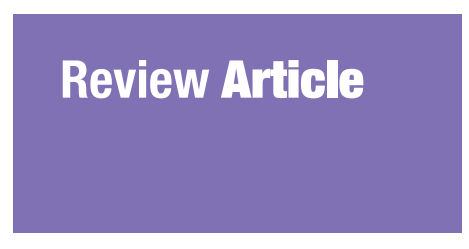

Submitted: 12 Jan 2017

Accepted: $28 \mathrm{Jul} 2017$

Online: 28 Feb 2018

\title{
Potential Benefits of Annona muricata in Combating Cancer: A Review
}

\author{
Aidy Irman YAJID ${ }^{1}$, Husna Syakirah AB RaHMAN ${ }^{2}$, Michael Wong \\ Pak Kai $^{2}$, Wan Zainira WAN ZAIN ${ }^{2}$
}

1 Department of Pathology, School of Medical Sciences, Universiti Sains Malaysia, 16150 Kubang Kerian, Kelantan, Malaysia

2 Department of Surgery, School of Medical Sciences, Universiti Sains Malaysia, 16150 Kubang Kerian, Kelantan, Malaysia

To cite this article: Yajid AI, Ab Rahman HS, Wong MPK, Wan Zain WZ. Potential benefits of Annona muricata in combating cancer: a review. Malays J Med Sci. 2018;25(1):5-15. https://doi.org/10.21315/mjms2018.25.1.2

To link to this article: https://doi.org/10.21315/mjms2018.25.1.2

\begin{abstract}
The incidence of cancer is increasing each year, which generates concerns regarding the efficacy of the current treatment options. This has caused patients to seek alternatives to complement or to replace surgery, chemotherapy and radiotherapy. Annona muricata and other plants have been shown to have promising compounds that can be utilised in the treatment of cancer. Native to the tropical and subtropical parts of the world, $A$. muricata plant extracts contain compounds that are particularly effective against cancer cells. In light of increasing concerns regarding the limitations of cancer treatment in hospitals, this review attempts to highlight the benefits of $A$. muricata and its potential to be integrated as one of the treatment options against cancer.
\end{abstract}

Keywords: Annona muricata, cancer, traditional, complementary, treatment

\section{Introduction}

Cancer, including breast cancer, has become a major health concern worldwide. It is estimated by the World Health Organization (WHO) that in the period between 2005 and 2015, 84 million deaths would be attributed to cancer (1). In the United States, an estimate shows that approximately 600,000 deaths will occur among Americans in the year 2016 due to cancer, with the most common including the lung, prostate and colorectum in men and the breast, bronchus and colorectum in women (2).

In Malaysia, a similar trend was also observed. The National Cancer Registry reported that breast cancer (18\%) is the most frequent cancer among the Malaysian population, followed by colorectal cancer (12.3\%) and lung cancer (10.2\%) (3). Based on the latest press statement by the Director General of Health Malaysia, of all deaths in hospitals linked to the Ministry of Health Malaysia, cancer has contributed to $13.56 \%$ of these deaths (4). The press statement also reported that in 2016, the trend in terms of most common cancers remained consistent, as reported by Zainal Ariffin dan Nor Saleha (3). The five most common cancers in the Malaysian male population are colorectum, lung, nasopharynx, lymphoma and prostate cancers, whereas in Malaysian female, the most common cancers are breast, colorectum, cervix uteri, ovary and lung cancers.

Although major breakthroughs have been achieved in the field of surgery, chemotherapy and radiotherapy, many still express concerns regarding these methods of treatment due to their limitations and, most noticeably, their side effects. Conventional $3 \mathrm{D}$ radiation therapy has been shown to be effective in the treatment of head and neck cancers, but the side effects that follow often cause discomfort and reductions in the quality of life among patients. Such side effects include xerostomia, which results in 
weight loss, and prolonged infections within the oral cavity and dental cavities (5). Although the development of intensity modulated radiotherapy (IMRT) to replace conventional radiation therapy allows the parotid glands to be spared (6) and results in an overall increase in the quality of life of patients (7), exposure to high doses of IMRT radiation reportedly causes dysphagia in patients (8).

Apart from the obvious toxicity induced by chemotherapy, another side effect that might appear following radiotherapy is hypothyroidism. In the case of head and neck cancer radiotherapy, it is estimated that $20 \%-25 \%$ of patients are diagnosed with hypothyroidism following 10 years of radiation therapy. Chemotherapy is also considered to be hazardous when administered to older patients. A study conducted by the Southwest Oncology Group on the induction of neuropathy in patients aged 65 years old and above showed an increase in the incidence of neuropathy in patients due to the toxicity of the taxane-based chemotherapy agent. The incidence of neuropathy was also shown to be particularly higher in patients diagnosed with diabetes (9). Cisplatin is another example of a chemotherapy agent that is associated with negative side effects in patients diagnosed with malignancies. Although cisplatin treatment against testicular cancer was shown to be effective in increasing the 5 -year survival rate to higher than $95 \%$ (10), it was also associated with negative secondary side effects, such as heart problems, toxicity in the nervous system, lung toxicity and the development of secondary malignancies in patients (11). Furthermore, cisplatin was also shown to be responsible in the generation of mutated red blood cells, and it was further suggested that such observation might be because of stem cells mutagenesis (12).

These issues, among others, have created a significant distrust towards cancer management procedures in hospitals and have caused patients to seek treatment elsewhere, especially from traditional medications, whether as a complementary treatment alongside conventional medications or as a way to improve their health without the treatments offered by hospitals. Although these traditional medications pose many issues regarding toxicity and efficacy due to the lack of high-quality studies, these remedies should not be completely left out as potential treatments. Based on cell cultures and animal studies, multiple bodies of evidence have been put forward in the scientific community regarding the potential use of traditional medications as a means to treat illnesses, including cancer. In this review, we explore some of the benefits of complementary and alternative medicines (CAMs), particularly Annona muricata, as potential treatments agent against breast cancer and other forms of cancer.

\section{Complementary and Alternative Medicine}

Complementary and alternative medicine is defined as means of treatment that are outside the scope of modern medicinal treatment. These treatments may be used as therapeutic and preventative agents to assist in combating physical or mental illnesses. They have been widely used for generations to treat illnesses prior to the arrival of modern medicine. Since the establishment of modern medicine, CAM has been used in conjunction with current treatment methods in certain countries to help and assist patient recovery (13). These types of treatments include natural products supplements, such as fish oil; body practices, such as yoga, Tai Chi or Qigong; and mind relaxation techniques, such as meditation and hypnotherapy (14).

In recent years, CAM has become more popular among the public, especially among cancer patients. A study by Corner (15) showed that out of 304 patients within Southampton and South-west Hampshire, a total of $81 \%$ patients used CAM, prior to or within 6 months of cancer diagnosis (15). The widespread use of CAM was also reported in national surveys conducted in countries such as England (16), Japan (17), United States (18), Germany (19) and Australia (20).

In addition to benefits in terms of improving the health of users, the ingredients used in CAM that are usually extracted from resources such as plants and animals are assumed to be safe for consumption. Another major attraction of CAM is that the source materials are cheap and readily available or easily planted for personal use. More importantly, the invasive procedures and adverse effects associated with medical treatments such as radiotherapy and chemotherapy often lead many to seek CAM as their main source of treatment.

In Malaysia, CAMs are also sought due to their benefits in improving health. More importantly, these CAMs have been used and practiced traditionally for centuries among Malaysians. A nationwide study conducted to 
examine the popularity of CAM in the Malaysian population revealed that the majority of Malaysians who participated in the study have used therapies that were biologically based for solving health issues and for improving and maintaining overall health (21). Some examples include 'daun misai kucing' (Orthosiphon stamineus), which has been shown to assist in improving hypertension (22) and to have antiangiogenic capabilities (23). Other examples are 'tualang honey' (24), 'ikan haruan' and Channa striatus (snakehead) (25), as well as 'gamat' (Holothuria tubulosa) (26), which have been associated with the capacity to enhance wound healing. A. muricata, (also known as graviola or soursop leaves) is also one of the more famous herbal treatments in Malaysia and worldwide, and its benefits are well known (27).

\section{Annona muricata}

Graviola (A. muricata) is a part of the Annonaceae family of plants $(28,29)$ and can be found in many parts of the tropical and subtropical parts of the world, including some parts of the Americas, Asia and Africa (30). The tropical plant is characterised as an evergreen and flowering tree that can stand up to 8 metres tall and that produces edible fruits (31). Most parts of the plant are used in traditional medications in treating various diseases and ailments (see Figure 1), including inflammation (32), rheumatism (28), diabetes (33), hypertension (34) and parasitic infestation (35).

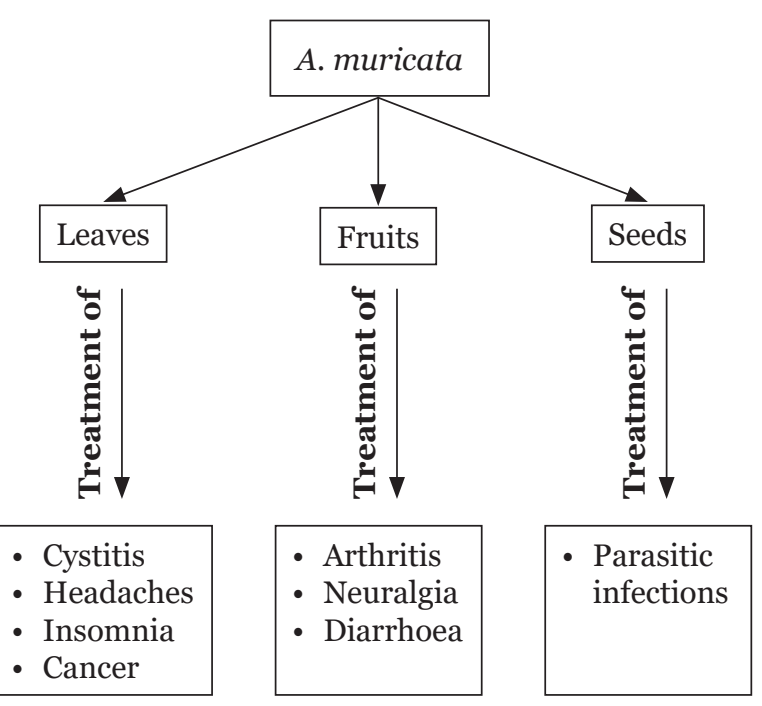

Figure 1. Benefits of $A$. muricata extracts in the treatment of illnesses (1)
The seed is extracted and used to fight against worms, while the fruits are used traditionally to cure arthritis and fever. Both the seeds and fruits are also used to treat parasitic infections. The leaves are used as a traditional medication to fight against collapses (36), hypoglycaemia, inflammation and as a relief medication against spasms (28). The leaf of the plant has been nicknamed "the cancer killer" and, as the name suggests, is also used in traditional medicine in the treatment of cancer $(27,37)$.

The plant has been used widely as a source of chemically active metabolites due to their various curative properties and is thus considered as a good candidate to be used as a complementary medicine. A phytochemical composition analysis of $A$. muricata by Gavamukulya (31) indicated that extracts from the plant contain a high concentration of secondary class metabolite compounds, such as alkaloids, saponins, terpenoids, flavonoids, coumarins and other lactones, anthroquinones, tannins, cardiac glucosides, phenols and phytosterols (38). These compounds are called Annonaceous acetogenins (AGEs), which were shown to induce cell cytotoxicity by inhibiting the mitochondrial complex I (39). Other studies have also suggested the presence of compounds such as megastigmanes (40), cyclopeptides and essential oils $(41,42)$, as well as essential minerals, such as $\mathrm{K}, \mathrm{Ca}, \mathrm{Na}, \mathrm{Cu}, \mathrm{Fe}$ and $\mathrm{Mg}$ (43).

A study by George also showed great potential for the use of $A$. muricata extracts in medicine. The study showed that the n-butanolic leaf extract of $A$. muricata might have potential utility for the development of therapeutically active compounds that could serve as precursors and/or chemical templates for the design of effective, more potent drugs in its class (44).

\section{Annonaceous Acetogenins}

Within the 212 compounds that were isolated from different parts of the plant, acetogenins (AGEs) were reported to be the major phytochemicals, followed by alkaloids and phenols (45). These secondary metabolites were first isolated from multiple parts of plants belonging to the Annonaceae family in 1982 by Tempesta, and acetogenins were further determined to have toxicity towards the $\mathrm{P}-388$ lymphocytic leukaemia in mice (46). Since then, more than 120 AGEs have been identified from ethanol, methanol or organic-based extracts from different parts of the plant, ranging from 
the leaves and the seeds (47) to even the fruit's outer skin.

AGEs were later determined to be metabolites that can be distinguished by the presence of a methyl-substituted $\alpha, \beta$-unsaturated $\gamma$-lactone (48). Since their discovery, more than 500 AGEs have been discovered from different parts of the plant (33). These metabolites were later classified into several groups on the basis of the availability of tetrahydrofuran (THF) and hydroxyl groups, as well as on factors such as the terminal $\gamma$-lactone ring and the characteristics aliphatic chain substituents (49). On the basis of these characteristics, AGEs can be divided into 10 different types, which include 1) linear AGEs (AGEs without the THF rings), 2) epoxyAGEs (without THF rings), 3) AGEs with monoTHF $\alpha, \alpha$-dihydroxylated $\gamma$-lactone, 4) AGEs with a mono-THF $\alpha$-hydroxylated $\gamma$-lactone, 5) AGEs with mono-THF and several lactone moieties, 6) AGEs with a neighbouring bis-THF $\alpha, \alpha$-dihydroxylated $\gamma$-lactone, 7) AGEs with a neighbouring bis-THF $\alpha$-hydroxylated $\gamma$-lactone, 8) AGEs with a non-adjacent bis-THF $\gamma$-lactone, 9) AGEs with a saturated lactone bis-THF and 10) miscellaneous AGEs (50).

Multiple forms of AGEs have been studied for their mechanisms that can be used against particular targets, such as insects and tumour cells. Acetogenins have been shown to be very effective against insects and can be used as insecticides and insect repellent. Multiple parts of the plant, including the roots, leaves, unripe fruits and seeds, have been shown to have insecticide and insect repellent properties (51), (52), (53). Against the larva of the moth Plutella xylostella, a pest of cabbage, $5 \mathrm{mg} /$ $\mathrm{mL}$ ethanolic extracts of $A$. muricata leaves were proven to be effective in killing $100 \%$ of the larvae tested. Further tests using lower concentrations of the ethanolic extracts even showed an ability to significantly reduce the survival of the larvae population (54). Crude extracts from the plant were also shown to be effective against Aedes aegypti, in combination with silver nanoparticles, which makes $A$. muricata extracts a good candidate to be used to control the spread of dengue fever (55). A similar anti-parasitic effect was also observed when methanolic extracts of the seed were used against Entamoeba histoltica, Molinema dessetae and Artemia salina, which was later deduced to be due to the presence of acetogenins (56). The role of acetogenins in inhibiting the growth of insect larvae was suggested to be due to the THF ring inhibition of the mitrochondrial complex I through NADH oxidase inhibition (52).

The capacity of acetogenins to inhibit $\mathrm{NADH}$ oxidase was also shown to be important for their anti-tumour function. The inhibition of $\mathrm{NADH}$ function is evident, as reported by Morré et al. The report suggested that exposure to an acetogenin called bullatacin specifically inhibited NADH oxidase enzyme functions isolated from Hela cells as HL-6o cancer cells (57).

Acetogenins were also shown to be capable of blocking ATP production in mitochondria. This mechanism of action was shown to be effective against cancer cells that produce higher amounts of ATP in comparison to normal cells, thus limiting the ability of cancer cells to grow (58). Interestingly, AGE toxicity was observed in the cancer cells, with a minimal negative impact on the normal cells. Studies using AA mimetics have suggested that acetogenin analogues synthesised in vitro have shown toxicity towards the HCT-8 and HT29 cell lines, with negative toxicity towards the normal human cell line HELF (59). Similarly, a study using A. muricata leaf extracts also showed toxicity towards cancer cell lines MCF-7, MDA-MB-231 and 4 T1, but less toxicity towards the normal breast cell, MCF10A (60), which shows that these AGEs specifically target cancer cells, not normal cells. These observations thus suggest the potential use of AGEs as treatment options against cancer.

\section{A. muricata and Its Biological Properties against Cancer}

A dysfunctional apoptotic pathway is one of the main contributors to carcinogenesis. The inability of cells to execute apoptosis to remove cancer cells was observed in multiple cancer types, including breast, pancreatic, ovarian and colorectal cancers (61-65). This occurrence creates imbalances between cell proliferation and cell death and can be caused by disruptions in the normal functions of the apoptotic pathway. Similar to other types of cancer, failure to carry out apoptosis in breast cancer cells might be attributed to the disruptions within the apoptotic pathway. Defects within the intrinsic pathway, for example, have been associated with the progression of breast cancer. Defects in the regulation of cytochrome release (66), apoptosome formation (67) and caspase activation (68) have all been shown to be present within breast cancer cells.

The capability of inducing cancer cell cytotoxicity has been one of the main reasons 
behind the increased interest among scientists in the benefits of CAM, especially plant-based CAMs. A. muricata leaves, among other CAMs, are good candidates to treat cancer caused by viruses. Extracts from A. muricata leaves were shown to have the capacity to induce apoptosis in Hela cells, suggesting that the extracts have the potential to be used as a treatment against virus-induced cancer cells (69). Such a potential was also evident in the prevention of skin papillomagenesis in laboratory mice. In this study, ethanolic extracts of $A$. muricata were shown to inhibit tumour growth in a two-stage skin papillomagenesis model, as evidenced by the presence of only slight hyperplasia in mice groups treated with $A$. muricata extracts in comparison to an untreated mice group (70).

\section{Breast Cancer}

In terms of specific effects against breast cancer, several studies have indicated the potential use of this plant in potential therapeutic treatments in patients. Extracts from $A$. muricata were shown to inhibit the proliferation of breast cancer cells by inducing cytotoxic activity in lung cancer cell lines (71). Gomes further reported that $A$. muricata extracts have the most cytotoxic effect when compared to extracts from Lantana camara, Handroanthus impetiginosus and Mentzella aspera. A separate study by Rachman et al. showed that the ethanol extracts of leaves of the soursop plant extracted into ethanol induce cytotoxic activity within the breast cancer cell line MCF7 (72). Another study by Gavamukulya also showed that a similar ethanol extract of the soursop plant leaves was found to be highly cytotoxic in vitro against the two human breast cancer cell lines MDA and SKBR3 (31).

\section{Liver Cancer}

The cytotoxic effect of the plant's extracts were also proposed by multiple in vitro studies using cultured liver cancer cells, suggesting that they can potentially be used as a treatment option against liver cancer. The growth and viability of the liver cancer cell HepG2 was shown to be inhibited following incubation with an ethanol extract of $A$. muricata. The cytotoxic effect observed in the HepG2 cell line was suggested to be a result of induction of the apoptosis pathway through the production of reactive oxygen species (ROS) (73). In a separate study using a similar cell line, Liu (74) also demonstrated the capability of $A$. muricata extracts to induce apoptosis. The study showed that the treatment of HepG2 resulted in the upregulation of heat shock protein 70 (HSP7O), glucose-regulated protein 94 (GRP94) and protein disulphide isomerase 5 (PDI-related protein 5). A bioinformatic analysis of the upregulation of these proteins suggested that the treatment of HepG2 cells with A. muricata extracts can trigger the apoptotic pathway by means of endoplasmic reticulum (ER) stress (74).

\section{Prostate Cancer}

Graviola leaf extract (GLE), flavonoidenriched extract and acetogenin-enriched extract (AEF) administered in vivo and in vitro were also shown to negatively affect the proliferation of prostate cancer. A study conducted by Yang (75) suggested that GLE, FEF and AEF all showed the capacity to down-regulate prostate cancer, with GLE being the most efficient at doing so. This study not only showed the efficacy of $A$. muricata extracts at inhibiting prostate cancer but also the importance of using whole-leaf extracts to achieve the highest inhibitor efficacy in combating cancer (75).

\section{Pancreatic Cancer}

A. muricata-induced cytotoxicity in cancer cells has also encouraged scientists to further examine the molecular pathways that lead to such observations. According to a study conducted by Torres et al. (76), the activation of extracellular signal-regulated kinases (ERK) and the phosphatidylinositol 3'kinases (PI3K/Akt) pathways play a crucial role in the proliferation and survival of pancreatic cancer cell, and the inhibition of these pathways leads to the inhibition of pancreatic cell growth. A similar study also revealed that the treatment of pancreatic cancer cells with $A$. muricata extracts resulted in a decrease in the activation of both ERK and Akt pathways in pancreatic cancer cells. Thus, the inhibition of these pathways is in agreement with the decreased viability of pancreatic cancer cells treated with the plant extract (76). Besides that, A. muricata was also shown to inhibit metastasis. A study performed on pancreatic cancer cells by Torres et al. (76) showed that the migratory capacity of pancreatic cancer cells was reduced after treatment with a graviola extract, as evaluated by a transwell assay, suggesting that the natural extract reduces the motility of pancreatic cancer cells. The motility and migration of cancer cells is associated with the arrangements of the cortical actin and microtubules network. Additionally, cellular ATP depletion has been associated with 
a reorganisation of the actin cytoskeleton and a suspension of the dynamics of microtubules, which is known to induce mitotic arrest. Thus, graviola extracts cause a disruption of the cortical actin network that can inhibit the motility of cancer cells (76).

\section{Lung Cancer}

Moghadamtousi et al. showed that $A$. muricata induces apoptosis in lung cancer cells (77). This finding was confirmed by high-content screening (HCS) multiple cytotoxicity analyses that examined the characteristics of apoptosis before and after treatment with $A$. muricata extracts, including nuclear condensation, mitochondrial membrane potential (MMP), cytochrome $c$ leakage and perturbation in membrane symmetry. The analyses showed that A549 cells treated with $A$. muricata extracts experience inhibition in growth capability as well as up-regulation of the apoptosis pathway.

\section{Colon Cancer}

Cancer is a disease caused by cell cycle dysfunction. The ability to block the cell cycle progression in cancer cells can effectively elevate the anti-cancer potential of natural products (78). A. muricata extracts, for example, were shown to have the potential to induce $\mathrm{G} 1$ cell cycle arrest (27). The study also showed that treatments of HCT116 and HT-29 cells resulted in the up-regulation of the apoptotic pathway, as suggested by an increase in the production of ROS, an increase in detectable cytochrome $c$, and an increase in initiator and executioner caspases in both of the tested cell lines. Furthermore, an increase in the levels of Bax protein was also observed by flow cytometry, which further suggested the activation of the apoptotic pathway (27).

\section{A. muricata Extracts in Conjunction with Conventional Treatment}

Despite the various benefits associated with the use of $A$. muricata extracts in inhibiting cancer cell lines, their usage alongside chemotherapy and radiation therapy has not been explored in such experiments and is in need of immediate attention. However, one cell culture-based study revealed a promising outlook on the potential use of these plant extracts alongside current radiotherapy and chemotherapy methods. The study, conducted at Sebelas Maret University in Indonesia, revealed a synergistic interaction between $A$. muricata
Linn leaves extracts with doxorubicin in reducing the development of Hela cells. In the study, 38.5 $\mu \mathrm{g} / \mathrm{mL}$ polyketide derivatives isolated from the plant were shown to have a synergistic effect with every concentration of doxorubicin used during the treatment of Hela cells (79).

\section{Conclusion}

Currently, many people are searching and trying alternate treatment methods for cancer, which is mainly attributed to the limitations of the current treatment methods for combating cancer. Treatments using A. muricata might offer an alternative choice besides chemotherapy and radiotherapy, especially for terminally ill patients. The benefits of utilising $A$. muricata extracts, as discussed above, suggest that these plant-based CAMs are potential treatment options against cancer. However, it is important to acknowledge that factors such as lifestyle and ignorance towards the symptoms of cancer are still major contributors to the increase in the incidence of cancer. A change to a better and healthier lifestyle and a better understanding and recognition of the signs and symptoms of cancer are needed to increase the chances of fighting cancer successfully. Further improvements to current treatment methods need to continue to allow the development of more efficient and less expensive treatment procedures against cancer. Malaysia is famous for its ethnic diversity and thus is rich in traditional medicine practices. CAMs, especially those associated with plants, have been widely used by various ethnicities for generations and should be used as a stepping stone to developing new ways to treat illnesses. In addition, research to integrate CAMs, such as A. muricata, into mainstream patient management procedures is important.

\section{Acknowledgements}

This publication was supported by Universiti Sains Malaysia short term grant (304/ PPSP/61313203).

\section{Authors' Contributions}

Drafting of the article: HSAR

Critical revision of the article for important intellectual content: AIY

Obtaining of funding: MWPK

Administrative, technical, or logistic support: WZWZ 


\section{Correspondence}

Dr Aidy Irman Yajid

BSc (Hons), PhD (University of Otago)

Department of Pathology,

School of Medical Sciences,

Universiti Sains Malaysia,

16150 Kubang Kerian, Kelantan, Malaysia.

Tel: +6010 9003237

Fax: +6097673370

E-mail: aidyirman84@gmail.com

\section{References}

1. Danhier F, Feron O, Préat V. To exploit the tumor microenvironment: passive and active tumor targeting of nanocarriers for anticancer drug delivery. $J$ Control Release. 2010;148(2):135-146. https://doi.org/10.1016/j. jconrel.2010.08.027

2. Siegel RL, Miller KD, Jemal A. Cancer statistics, 2016. Cancer Stat. 2016;66(1):7-30. https://doi. org/10.3322/caac.21332

3. Zainal Ariffin O, Nor Saleha I. National cancer registry report 2007. Malaysia: Ministry of Health; 2011.

4. Press Statement: Director General of Health Malaysia. The Malaysian National Cancer Registry Report [Internet]; 25 November 2016.

5. Wendt TG. Hazards and risks in oncology: radiation oncology. GMS Current Topics Otorhinolaryngology, Head Neck Surg. 2013;12.

6. Amosson CM, Teh BS, Van TJ, Uy N, Huang E, Mai W-Y, et al. Dosimetric predictors of xerostomia for head-and-neck cancer patients treated with the smart (simultaneous modulated accelerated radiation therapy) boost technique. Int J Radiat Oncol. 2003;56(1):136-144. https:// doi.org/10.1016/So360-3016(03)00093-2

7. Chen AM, Farwell DG, Luu Q, Vazquez EG, Lau DH, Purdy JA. Intensity-modulated radiotherapy is associated with improved global quality of life among long-term survivors of head-and-neck cancer. Int $J$ Radiat Oncol. 2012;84(1):170-175. https://doi.org/10.1016/j.ijrobp.2011.11.026

8. Van der Molen L, van Rossum MA, Burkhead LM, Smeele LE, Hilgers FJ. Functional outcomes and rehabilitation strategies in patients treated with chemoradiotherapy for advanced head and neck cancer: a systematic review. Eur Arc Oto-Rhino-L. 2009;266(6):889-900. https://doi.org/10.1007/ s00405-008-0817-3
9. Hershman DL, Till C, Wright JD, Awad D, Ramsey SD, Barlow WE, et al. Comorbidities and risk of chemotherapy-induced peripheral neuropathy among participants 65 years or older in Southwest Oncology Group clinical trials. $J$ Clin Oncol. 2016;34(25):3014-3022. https://doi. org/10.1200/JCO.2015.66.2346

10. Verdecchia A, Francisci S, Brenner H, Gatta G, Micheli A, Mangone L, et al. Recent cancer survival in Europe: a 2000-02 period analysis of EUROCARE-4 data. Lancet Oncol. 2007;8(9):784-796. https://doi.org/10.1016/ S1470-2045(07)70246-2

11. Travis LB, Beard C, Allan JM, Dahl AA, Feldman DR, Oldenburg $J$, et al. Testicular cancer survivorship: research strategies and recommendations. $J$ National Cancer Inst. 2010;102(15):1114-1130. https://doi. org/10.1093/jnci/djq216

12. Dertinger SD, Avlasevich SL, Torous DK, Bemis JC, Phonethepswath S, Labash C, et al. Persistence of cisplatin-induced mutagenicity in hematopoietic stem cells: implications for secondary cancer risk following chemotherapy. Toxicol Sci. 2014;140(2):307-314. https://doi. org/10.1093/toxsci/kfuo78

13. Falkenberg T, Lewith G, Roberti di Sarsina P, Von Ammon K, Santos-Rey K, Hök J, et al. Towards a pan-European definition of complementary and alternative medicine-a realistic ambition? Forschende Komplementärmedizin/Res Complementary Med. 2012;19(Suppl 2):6-8.

14. Sirois FM, Gick ML. An investigation of the health beliefs and motivations of complementary medicine clients. Soc Sci Med. 2002;55(6):10251037. https://doi.org/10.1016/So277-9536(01) 00229-5

15. Corner J, Yardley J, Maher E, Roffe L, Young $\mathrm{T}$, Maslin-Prothero S, et al. Patterns of complementary and alternative medicine use among patients undergoing cancer treatment. Eur $J$ Cancer Care. 2009;18(3):271-279. https://doi. org/10.1111/j.1365-2354.2007.00911.x

16. Hunt KJ, Coelho HF, Wider B, Perry R, Hung S, Terry R, et al. Complementary and alternative medicine use in England: results from a national survey. Int J Clin Pract. 2010;64(11):1496-1502. https://doi.org/10.1111/j.1742-1241.2010.02484.x 
17. Yamashita H, Tsukayama H, Sugishita C. Popularity of complementary and alternative medicine in Japan: a telephone survey. Complement Therap Med. 2002;10(2):84-93. https://doi.org/10.1054/ctim.2002.0519

18. Barnes PM, Bloom B, Nahin RL. Complementary and alternative medicine use among adults and children: United States, 2007. US Department of Health and Human Services, Centers for Disease Control and Prevention, National Center for Health Statistics Hyattsville, MD; 2008.

19. Härtel U, Volger E. [Use and acceptance of classical natural and alternative medicine in Germany-findings of a representative population-based survey]. Forschende Komplementarmedizin und klassische Naturheilkunde/Res Complement Nat Classical Med. 2004;11(6):327-334.

20. Xue CC, Zhang AL, Lin V, Da Costa C, Story DF. Complementary and alternative medicine use in Australia: a national population-based survey. $J$ Alt Complement Med. 2007;13(6):643-650. https://doi.org/10.1089/acm.2006.6355

21. Siti Z, Tahir A, Farah AI, Fazlin SA, Sondi S, Azman A, et al. Use of traditional and complementary medicine in Malaysia: a baseline study. Complement Ther Med. 2009;17(5):292299. https://doi.org/10.1016/j.ctim.2009.04.002

22. Saidan NH, Hamil MS, Memon AH, Abdelbari MM, Hamdan MR, Mohd KS, et al. Selected metabolites profiling of Orthosiphon stamineus Benth leaves extracts combined with chemometrics analysis and correlation with biological activities. BMC Complement Alt Med. 2015;15(1):350. https://doi.org/10.1186/s12906015-0884-o. PubMed PMID: 26446501; PubMed Central PMCID: PMC4597610.

23. Siddiqui M, Hafizoh S, Ismail Z, Sahib H, Helal M, Majid AA. Analysis of total proteins, polysaccharides and glycosaponins contents of orthosiphon stamineus benth. in spray and freeze dried methanol: water (1:1) extract and its contribution to cytotoxic and antiangiogenic activities. Pharmacogn Res. 2009;1(5):320.

24. Fauzi AN, Norazmi MN, Yaacob NS. Tualang honey induces apoptosis and disrupts the mitochondrial membrane potential of human breast and cervical cancer cell lines. Food Chem Toxicol. 2011;49(4):871-878. https://doi.org/ 10.1016/j.fct.2010.12.010. PubMed PMID: 21167897 .
25. Ab Wahab SZ, Abdul Kadir A, Nik Hussain $\mathrm{NH}$, Omar J, Yunus R, Baie S, et al. The effect of Channa striatus (haruan) extract on pain and wound healing of post-lower segment caesarean section women. Evid-Based Compl Alt Med: eCAM. 2015;2015:849647. https://doi.org/10.1155/2015/849647. PubMed PMID: 26101537; PubMed Central PMCID: PMC4458554.

26. Vazzana M, Siragusa T, Arizza V, Buscaino G, Celi M. Cellular responses and HSP7O expression during wound healing in Holothuria tubulosa (Gmelin, 1788). Fish Shellfish Immun. 2015;42(2):306-315. https://doi.org/10.1016/j. fsi.2014.11.010. PubMed PMID: 25463287.

27. Moghadamtousi SZ, Karimian H, Rouhollahi E, Paydar M, Fadaeinasab M, Abdul Kadir H. Annona muricata leaves induce G(1) cell cycle arrest and apoptosis through mitochondriamediated pathway in human HCT-116 and HT-29 colon cancer cells. $J$ Ethnopharmacol. 2014;156:277-289. https://doi.org/10.1016/j. jep.2014.08.011. PubMed PMID: 25195082.

28. Mishra S, Ahmad S, Kumar N, Sharma B. Annona muricata (the cancer killer): a review. Glob $J$ Pharma Res. 2013;2(1):1613-1618.

29. Leboeuf M, Cavé A, Bhaumik P, Mukherjee B, Mukherjee R. The phytochemistry of the Annonaceae. Phytochemistry. 1980;21(12): 2783-2813. https://doi.org/10.1016/o031-9422 (80)85046-1

30. Adewole SO, Caxton-Martins EA. Morphological changes and hypoglycemic effects of Annona muricata linn.(annonaceae) leaf aqueous extract on pancreatic $\beta$-cells of streptozotocin-treated diabetic rats. Afr J Biomed Res. 2006;9(3):173180 .

31. da Silva RR. Enhanced extraction yields and mobile phase separations by solvent mixtures for the analysis of metabolites in Annona muricata L. leaves. Analysis. 2009;9:10.

32. Hamid RA, Foong CP, Ahmad Z, Hussain MK. Antinociceptive and anti-ulcerogenic activities of the ethanolic extract of Annona muricata leaf. Revista Brasileira de Farmacognosia. 2012;22(3):630-641. https://doi.org/10.1590/ So102-695X2012005000001 
33. Moghadamtousi SZ, Fadaeinasab M, Nikzad S, Mohan G, Ali HM, Kadir HA. Annona muricata (Annonaceae): a review of its traditional uses, isolated acetogenins and biological activities. Int J Mol Sci. 2015;16(7):15625-15658. https://doi. org/10.339o/ijms160715625

34. Brussell DE. A medicinal plant collection from Montserrat, West Indies. Econ Bot. 2004;58:S203-S220. https://doi.org/10.1663/ 0013-0001(2004)58[S203:AMPCFM]2.0.CO;2

35. Kamaraj C, Rahuman AA. Efficacy of anthelmintic properties of medicinal plant extracts against Haemonchus contortus. Res Vet Sci. 2011;91(3):400-404. https://doi.org/10.1016/j. rvsc.2010.09.018

36. Ong $\mathrm{H}$, Norzalina J. Malay herbal medicine in gemencheh, Negri Sembilan, Malaysia. Fitoterapia. 1999;70(1):10-14. https://doi.org/ 10.1016/So367-326X(98)ooo23-9

37. Adewole S, Ojewole J. Protective effects of Annona muricata Linn.(Annonaceae) leaf aqueous extract on serum lipid profiles and oxidative stress in hepatocytes of streptozotocintreated diabetic rats. Afr $J$ Tradit Complem. 2009;6(1):30-41.

38. Gavamukulya Y, Abou-Elella F, Wamunyokoli F, $\mathrm{H}$ AE-S. Phytochemical screening, anti-oxidant activity and in vitro anticancer potential of ethanolic and water leaves extracts of Annona muricata (Graviola). Asian Pac J Trop Med. 2014;7(Suppl 1):S355-S363. https://doi.org/ 10.1016/S1995-7645(14)60258-3. PubMed PMID: 25312150 .

39. Sies H. Strategies of antioxidant defense. Eur $J$ Biochem/FEBS. 1993;215(2):213-219. PubMed PMID: 7688300.

40. Matsushige A, Matsunami K, Kotake Y, Otsuka $\mathrm{H}$, Ohta S. Three new megastigmanes from the leaves of Annona muricata. J Nat Med. 2012;66(2):284-291. https://doi.org/10.1007/ S11418-011-0583-1

41. Pélissier Y, Marion C, Kone D, Lamaty G, Menut C, Bessière J-M. Volatile components of Annona muricata L. J Essent Oil Res. 1994;6(4):411-414. https://doi.org/10.1080/10412905.1994.9698410

42. Kossouoh C, Moudachirou M, Adjakidje V, Chalchat J-C, Figuérédo G. Essential oil chemical composition of Annona muricata L. leaves from Benin. J Essent Oil Res. 2007;19(4):307-309. https://doi.org/10.1080/10412905.2007.9699288
43. Gyamfi K, Sarfo D, Nyarko B, Akaho E, SerforArmah Y, Ampomah-Amoako E. Assessment of elemental content in the fruit of graviola plant, Annona muricata, from some selected communities in ghana by instrumental neutron activation analysis. Elixir Food Sci. 2011;41:5671-5675.

44. George VC, Kumar DR, Rajkumar V, Suresh PK, Kumar RA. Quantitative assessment of the relative antineoplastic potential of the n-butanolic leaf extract of Annona muricata Linn. in normal and immortalized human cell lines. Asian Pac $J$ Cancer Prev. 2012;13(2):699-704. https:// doi.org/10.7314/APJCP.2012.13.2.699. PubMed PMID: 22524847.

45. Coria-Téllez AV, Montalvo-Gónzalez E, Yahia EM, Obledo-Vázquez EN. Annona muricata: A comprehensive review on its traditional medicinal uses, phytochemicals, pharmacological activities, mechanisms of action and toxicity. Arabian J Chem. 2016. https://doi.org/10.1016/j. arabjc.2016.01.004

46. Tempesta MS, Kriek GR, Bates RB. Uvaricin, a new antitumor agent from Uvaria accuminata (Annonaceae). J Org Chem. 1982;47(16):31513153. https://doi.org/10.1021/joo0137a024

47. Chang F-R, Liaw C-C, Lin C-Y, Chou C-J, Chiu $\mathrm{H}-\mathrm{F}, \mathrm{Wu}$ Y-C. New adjacent bis-tetrahydrofuran annonaceous acetogenins from Annona muricata. Planta Medica. 2003;69(03):241-246. https:// doi.org/10.1055/s-2003-38485

48. Jirovetz L, Buchbauer G, Ngassoum MB. Essential oil compounds of the Annona muricata fresh fruit pulp from Cameroon. J Agric Food Chem. 1998;46(9):3719-3720. https://doi.org/10.1021/ jf980204n

49. Zafra-Polo MC, Figadère $\mathrm{B}$, Gallardo $\mathrm{T}$, Tormo J, Cortes D. Natural acetogenins from Annonaceae, synthesis and mechanisms of action. Phytochemistry. 1998;48(7):1087-1117. https:// doi.org/10.1016/Soo31-9422(97)00917-5

50. Liaw C-C, Liou J-R, Wu T-Y, Chang F-R, Wu Y-C. Acetogenins from Annonaceae. Prog Ch Org Nat Prod 101. 2016;113-230. https://doi. org/10.1007/978-3-319-22692-7_2

51. Brechelt A. El manejo ecológico de plagas y enfermedades. Red de Acción en Plaguicidas y sus Alternativas para América Latina (RAP-AL) Fundación Agricultura y Medio Ambiente (FAMA) $\mathrm{RD} ; 2004$. 
52. Isman MB, Akhtar Y. Plant natural products as a source for developing environmentally acceptable insecticides. Insecticides Design Using Adv Tech; 2007:235-248. https://doi.org/10.1007/978-3540-46907-0_10

53. Leatemia JA, Isman MB. Insecticidal activity of crude seed extracts of Annona spp., Lansium domesticum and Sandoricum koetjape against lepidopteran larvae. Phytoparasitica. 2004;32(1):30-37. https://doi.org/10.1007/ BFo2980856

54. Trindade P, Cristina R, De Souza Luna J, Ferreira De Lima MR, Da Silva PP, Goulart Sant'ana AE. Larvicidal activity and seasonal variation of Annona muricata (Annonaceae) extract on Plutella xylostella (Lepidoptera: Plutellidae). Revista Colombiana de Entomología. 2011;37(2):223-227.

55. Santhosh SB, Ragavendran C, Natarajan D. Spectral and HRTEM analyses of Annona muricata leaf extract mediated silver nanoparticles and its larvicidal efficacy against three mosquito vectors Anopheles stephensi, Culex quinquefasciatus, and Aedes aegypti. $J$ Photoch Photobio B. 2015;153:184-190. https://doi.org/10.1016/j.jphotobiol.2015.09.018

56. Bories C, Loiseau P, Cortes D, Myint $\mathrm{SH}$, Hocquemiller R, Gayral $\mathrm{P}$, et al. Antiparasitic activity of Annona muricata and Annona cherimolia seeds. Planta Medica. 1991;57(o5):434-436. https://doi. org/10.1055/s-2006-960143

57. Morré DJ, de Cabo R, Farley C, Oberlies NH, McLaughlin JL. Mode of action of bullatacin, a potent antitumor acetogenin: inhibition of NADH oxidase activity of HeLa and HL-6o, but not liver, plasma membranes. Life Sci. 1994;56(5):343-348. https://doi.org/10.1016/ 0024-3205(94)00957-0

58. Waechter A-I, Hocquemiller R, Laurens A, Cavé A. Glaucafilin, an acetogenin from Annona glauca. Phytochemistry. 1997;44(8):1537-1540. https://doi.org/10.1016/Soo31-9422(96)00764-9

59. Zeng BB, Wu Y, Jiang S, Yu Q, Yao ZJ, Liu ZH, et al. Studies on mimicry of naturally occurring Annonaceous acetogenins: non-THF analogues leading to remarkable selective cytotoxicity against human tumor cells. Chemistry-An European Journal. 2003;9(1):282-290. https:// doi.org/10.1002/chem.200390021
60. Najmuddin SUFS, Romli MF, Hamid M, Alitheen NB, Rahman NMANA. Anti-cancer effect of Annona muricata Linn leaves crude extract (AMCE) on breast cancer cell line. BMC Complement Alt Med. 2016;16(1):311. https:// doi.org/10.1186/s12906-016-1290-y

61. Olopade OI, Adeyanju MO, Safa AR, Hagos F, Mick R, Thompson CB, et al. Overexpression of BCL-x protein in primary breast cancer is associated with high tumor grade and nodal metastases. Cancer J Sci Amer. 1996;3(4):230237.

62. Friess $\mathrm{H}, \mathrm{Lu} \mathrm{Z}$, Andrén-Sandberg A, Berberat P, Zimmermann A, Adler G, et al. Moderate activation of the apoptosis inhibitor bcl-xL worsens the prognosis in pancreatic cancer. Ann Surg. 1998;228(6):780. https://doi.org/ 10.1097/00000658-199812000-00009

63. Marone M, Scambia G, Mozzetti S, Ferrandina G, Iacovella $S$, De Pasqua A, et al. bcl-2, bax, bcl-XL, and bcl-XS expression in normal and neoplastic ovarian tissues. Clin Cancer Res. 1998;4(2):517524 .

64. Biroccio A, Benassi B, D’Agnano I, D’Angelo C, Buglioni S, Mottolese M, et al. c-Myb and Bcl-x overexpression predicts poor prognosis in colorectal cancer: clinical and experimental findings. Amer J Pathol. 2001;158(4):12891299. https://doi.org/10.1016/Sooo2-9440(10) 64080-1

65. Rubio N, España L, Fernández Y, Blanco J, Sierra A. Metastatic behavior of human breast carcinomas overexpressing the Bcl-xL gene: a role in dormancy and organospecificity. Lab Invest. 2001;81(5):725-734. https://doi.org/10.1038/ labinvest.3780281

66. Bellacosa A, De Feo D, Godwin AK, Bell DW, Cheng JQ, Altomare DA, et al. Molecular alterations of the AKT2 oncogene in ovarian and breast carcinomas. Int $J$ Cancer. 1995;64(4):280-285. https://doi.org/10.1002/ ijc.2910640412

67. Magdalena C, Dominguez F, Loidi L, Puente J. Tumour prothymosin alpha content, a potential prognostic marker for primary breast cancer. Br J Cancer. 2000;82(3):584. 
68. Grossman D, McNiff JM, Li F, Altieri DC. Expression and targeting of the apoptosis inhibitor, survivin, in human melanoma. J Invest Dermatol. 1999;113(6):1076-1081. https://doi. org/10.1046/j.1523-1747.1999.00776.x

69. Astirin OP, Artanti AN, Fitria MS, Perwitasari EA. Annona muricata linn leaf induce apoptosis in cancer cause virus. $J$ Cancer Ther. 2013;4:12441250. https://doi.org/10.4236/jct.2013.47146

70. Hamizah S, Roslida A, Fezah O, Tan K, Tor Y, Tan C. Chemopreventive potential of Annona muricata $L$ leaves on chemically-induced skin papillomagenesis in mice. Asian Pac $J$ Cancer Prev. 2012;13(6):2533-2539. https://doi.org/ 10.7314/APJCP.2012.13.6.2533

71. Gomes de Melo J, de Sousa Araújo TA, Thijan Nobre de Almeida e Castro V, Lyra de Vasconcelos Cabral D, Do Desterro Rodrigues M, Carneiro do Nascimento $\mathrm{S}$, et al. Antiproliferative activity, antioxidant capacity and tannin content in plants of semi-arid northeastern Brazil. Molecules. 2010;15(12):8534-8542. https://doi. org/10.3390/molecules15128534

72. Rachman EPN, Suhesti TS, Widiastuti R, Aditiyono A, editors. Cytotoxic effects of methanol extracts of soursop leaves (Annona muricata) on MCF-7 cell line and its effect on expression of BCL-2. ASEAN/Asian Academic Society International Conference Proceeding Series; 2013.

73. Yang H, Liu N, Lee S. Ethanol extract of Annona muricata $L$ induces liver cancer cell apoptosis through ROS pathway. Biomedical and Pharmacology Journal. 2016;9(3):919-925. https://doi.org/10.13005/bpj/1030

74. Liu N, Yang HL, Wang P, Lu YC, Yang YJ, Wang $\mathrm{L}$, et al. Functional proteomic analysis revels that the ethanol extract of Annona muricata $L$. induces liver cancer cell apoptosis through endoplasmic reticulum stress pathway. Journal of Ethnopharmacology. 2016;189:210-217. https://doi.org/10.1016/j.jep.2016.05.045
75. Yang C, Gundala SR, Mukkavilli R, Vangala $\mathrm{S}$, Reid MD, Aneja R. Synergistic interactions among flavonoids and acetogenins in graviola (Annona muricata) leaves confer protection against prostate cancer. Carcinogenesis. 2015;36(6):656-665. https://doi.org/10.1093/ carcin/bgvo46

76. Torres MP, Rachagani S, Purohit V, Pandey P, Joshi S, Moore ED, et al. Graviola: a novel promising natural-derived drug that inhibits tumorigenicity and metastasis of pancreatic cancer cells in vitro and in vivo through altering cell metabolism. Cancer Letters. 2012;323(1):29-40. https://doi.org/10.1016/j. canlet.2012.03.031. PubMed PMID: 22475682; PubMed Central PMCID: PMC3371140.

77. Moghadamtousi SZ, Kadir HA, Paydar M, Rouhollahi E, Karimian H. Annona muricata leaves induced apoptosis in A549 cells through mitochondrial-mediated pathway and involvement of NF- $\mathrm{BB}$. BMC Complementary and Alternative Medicine. 2014;14(1):1. https://doi. org/10.1186/1472-6882-14-299

78. Mantena SK, Sharma SD, Katiyar SK. Berberine, a natural product, induces G1-phase cell cycle arrest and caspase-3-dependent apoptosis in human prostate carcinoma cells. Molecular Cancer Therapeutics. 2006;5(2):296-308. https://doi. org/10.1158/1535-7163.MCT-05-0448. PubMed PMID: 16505103 .

79. Artanti A, Astirin O, Prayito A, Widiyaningsih R, Prihapsara F, editors. Polyketide derivatives from Annona muricata linn leaves as potencial anticancer material by combination treatment with doxorubicin on Hela cell line. IOP Conference Series. Materials Science and Engineering: IOP Publishing; 2017. https://doi. org/10.1088/1757-899X/176/1/012002 